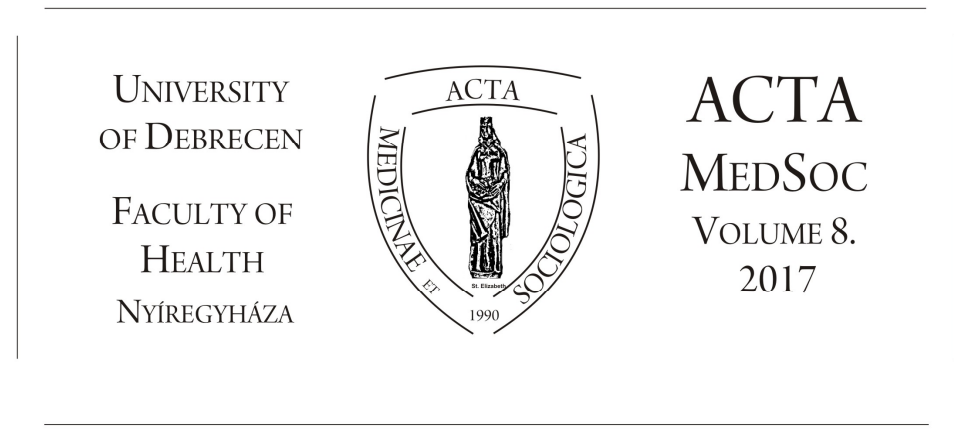

\title{
Felnőtt fejjel tanulni - egy nyíregyházi felzárkóztató képzés tanulságai
}

\author{
Nyilas Orsolya
}

Nyíregyházi Egyetem, Társadalom - és Kultúratudományi Intézet

\begin{abstract}
Adulthood learning - lessons of a catching-up program in Nyíregyháza. Adult population does not consider education as an investment to their own, long term human capital. They recognize it rather as compulsion, or a mean to avoid unemployment, even though one of the most important factors in reducing the disadvantaged situation. After all, during training one can acquirebest case scenario- not only knowledge, but the workers attitude to integrate into society, as well as the sense of social usefulness and a new vision for future appears ahead of the adult learner. In Hungarian andragogic discipline Durkó Mátyás views the care for the whole personality and individual development as highly important tasks of the adult education renewal (Durkó, 1999). The aim of the high priority project, code number GINOP-6.1.1-15 (GINOP-Economic Development and Innovation Operative Programme) "Training for the underqualified and for the public employed" is to encourage people with low educational attainment, who lack competences or qualifications required in the labour market, to participate in the adult training. The project is aimed to provide the possibility for these people to acquire the labour market relevant qualifications, knowledge, skills and competences. In the present study we took into considera-
\end{abstract}


tion the experience we gained through such training, examining the participants' joy, success, and hardships through the eyes of an andragogue. We did all these by using the method of observation and focus group interviews.

Keywords: adult education, disadvantage

DOI: $10.19055 / \mathrm{ams} .2017 .8 / 24 / 8$

\begin{abstract}
Absztrakt. A felnőtt populáció jellemzően nem tekinti hosszú távú, saját emberi tőkéjébe való befektetésnek, ha oktatásáról, képzéséről van szó. Sokkal inkább érzik kényszernek, esetleg a munkanélküliség elkerülésének egyik eszközét látják benne, holott a hátrányos helyzet mérséklésére alkalmas eszközök közül, a képzés az egyik legfontosabb tényező. Hiszen a képzés folyamán - jó estben - nem csak az ismeretszerzés, hanem a társadalomba integrálódni képes munkavállalói attitüd elérése is bekövetkezik, megjelenik a társadalmi hasznosságérzet és új jövőkép bontakozik ki a felnőtt tanuló előtt. A magyar andragógiai diszciplínában Durkó Mátyás kiemelkedően fontos feladatnak tekintette a felnőttnevelés megújításában a teljes személyiséggondozást és az egyéniség fejlesztését (Durkó, 1999). A GINOP-6.1.1-15 kódszámú „Alacsony képzettségüek és közfoglalkoztatottak képzése" címü kiemelt projekt célja, hogy ösztönözze az alacsony iskolai végzettséggel, munkaeröpiacon keresett kompetenciával vagy szakképesítéssel nem rendelkező felnőtt lakosság részvételét az oktatásban, képzésben, és lehetőséget biztosítson számukra a munkaerö-piaci szempontból releváns képzettség, ismeretek, készségek, kompetenciák megszerzésére. Jelen tanulmányban egy ilyen képzésben szerzett tapasztalatainkat vettük számba, andragógus szemmel vizsgálva a képzésben résztvevök örömeit, sikereit, nehézségeit. Mindezt megfigyeléses módszerrel valamint fókuszcsoportos interjúk segítségével tettük.
\end{abstract}

Kulcsszavak: felnőttképzés, hátrányos helyzet

\title{
Bevezető
}

Alapvető különbség az iskoláskorúak és a felnőttek tanulásában, hogy a gyerekek a tanultakat egy távoli jövőben akarják alkalmazni, míg a felnőttek a lehető leghamarabb szeretnék látni tanulmányaik gyakorlati hasznosulását. De nemcsak a képzési tartalmak kidolgozásánál fontos a tanultak hasznosíthatósága, hanem a felnőttoktatónak is tudatában kell lennie annak a ténynek, miszerint a tanulásban erős motiváló tényező az, ha az elsajátított tudás, a kifejlesztett kompetenciák alkalmazhatóságáról már a képzés során meggyőződhet a tanuló. A felnőttek tanulási döntéseiben fontos tényező a tanulás útján elérendő cél meghatározása, amely fakadhat belső és külső indítékokból. A tanulmányok teljesítésében számos motívum felbukkan, amelyek többnyire egy végcélban sürüsödnek össze, mégpe- 
dig a továbbtanulás vagy a munkaerő-piaci elhelyezkedés kapcsán kitüzött célban. A felnőttek tanulása kevésbé ilyen egyértelmüen lineáris szerkezetü. Hacsak nem kötelezettek valaki vagy valami által egy tanulmányi út bejárására, akkor szabadon dönthetnek a tanulás módjáról, tartalmáról, időzítéséről. Ebben a döntésmechanizmusban a tanulás útján elérni kívánt cél maga is motivációként funkcionálhat. Az sem újszerü megállapítás, hogy a felnőttek tanulása többnyire kényszer, mintsem érdeklődés vezérelte folyamat, legyen szó munkahelyi képzésről, közmunka programok képzéseiről, a felzárkóztató képzésekről nem is beszélve.

\section{Alacsony végezettség és a társadalmi helyzet}

Napjainkra sajnálatos ténnyé vált, hogy egyre többen sodródnak a társadalom peremére, az esélytelenek képzési hátránnyal küzdenek, és nem képesek bekapcsolódni a munka világába. A képzetlenek, munkanélküliek, esetleg más szempontból is hátrányos helyzetüek életformájává vált a munkanélküliség, a kulturális hátrányt pedig átszármaztathatják a következő generációra. Bár a felnőttoktatás és -képzés önmagában nem oldja meg a szegénység, a diszkrimináció és a szociális depriváció okozta problémákat, de képes hozzájárulni ezeknek a konfliktusoknak a feloldásához (Koltai, 1999).

Ferge Zsuzsa (2010) megállapította, hogy az egyéni döntések is erős társadalmi befolyás alatt születnek. Az iskolába történő beruházás mértéke sokkal nagyobb, ha naponta órákig tart az oda és visszautazás, és sokkal kisebb, ha néhány perc gyaloglásnyira van a középiskola. A kockázatok sokkal magasabbnak tünnek ott, ahol a középiskolát szinte soha senki nem végezte el (egyetemröl meg föiskoláról még csak nem is hallottak személyes ismerőstől), mint ott, ahol a személyes környezetben csaknem mindenki sikeresen elvégzett valamilyen egyetemet vagy főiskolát. Ebben a felvetésben racionális döntési helyzet az iskolaválasztás is, a továbbtanulás vagy a tovább nem tanulás melletti döntés is. Az iskolák folytatása vagy az iskolai karrier megszakítása mellett szólhatnak olyan mérlegelések, mint hogy „,megéri-e a várható munkaerő-piaci előnyök érdekében beruházni, költeni a további iskoláztatásra?”. Vagy hogy „nem jelent-e túl nagy kockázatot az, hogy csak a jó eredménnyel elvégzett magasabb iskolának van munkaerő-piaci értéke, a rossz eredménnyel megszerzett diplomának nincsen?”. Természetesen ezek az egyéni (vagy szülői) mérlegelési szempontok jelentősen befolyásolják az iskolai karrierek alakulását, és bár a „módszertani individualizmust" és a racionális döntések elméletét sokan kritizálják, azt még a kritikusok is kénytelenek elismerni, hogy az egyéni döntéseknek fontos társadalmi szerepük, jelentőségük van (Sen, 2009, idézi Ferge 2010). Az alacsony iskolázottság megértéséhez mind az egyéni, mind a társadalmi meghatározottságokat 
figyelembe kell venni. Olykor a középiskola választása túl kockázatos, túl költséges, és túl kicsi haszonnal járó befektetésnek tünik akkor, ha nincs mód a költségek finanszírozására, a gyerekkor meghosszabbítására, vagy ha a környezetben a magasabb végzettségüek sem tudnak semmilyen munkát találni. Másrészt az iskolaválasztást nagyban befolyásolhatják divatok, munkákhoz és szakmákhoz tapadó pozitív vagy negatív értékek, megbecsültségek vagy lenézettségek (Farkas, 2013).

A klasszikus oktatásszociológia által megállapított legerősebb társadalmi öszszefüggés: a szülők alacsony iskolai végzettsége, és ezzel együtt járó alacsony társadalmi státusza hat legerösebben a gyerekek alacsony iskolai végzettségére. $\mathrm{Az}$ alacsony iskolai végzettségü gyerekek szüleinek igen nagy arányban alacsony végzettségüek a szüleik is. A másik jelentős meghatározó tényező a területi egyenlőtlenségek leképeződése az alacsony iskolázottságra. Az iskolai hátrányok települési, területi elvű sürủsödését a hazai szakirodalom gyakran írja le a szegregáció fogalmával. A hátrányok ebben a felvetésben nem statisztikai öszszefüggésre, hanem erőteljes és csaknem átjárhatatlannak tünő elkülönülésre is utal a jobb és rosszabb iskolák, gyakorlatilag a jobb és rosszabb lakókörnyezetben fellelhető iskolák és diákjaik között (Fazekas-Köllö-Varga, 2008; KertesiKézdi, 2009a; Kertesi-Kézdi, 2009b).

\section{Iskolai végzettség és foglalkoztatás}

A magyarországi munkaerőpiac az európai államokhoz hasonlóan folyamatosan szükül. A munkaerö-piaci feltételek Magyarországon 1989 után átalakultak, tömegessé vált a munkanélküliség, amely leginkább az alacsony képzettségü csoportokat érintette. A munkaerőpiacról leszakadó rétegekhez elsősorban az iskolában sikertelen csoportok sorolhatók, így az általános iskolai végzettséggel nem rendelkezők, a speciális általános iskolába járók, akik nem tanulnak tovább középfokon, vagy onnan lemorzsolódnak, és a munkaerö-piaci igényeknek meg nem felelő szakképzésben részesült fiatalok (Farkas, 2013).

Az alacsonyabb iskolai végzettségüek az átlagosnál nagyobb valószínűséggel tapasztalják meg a munkanélküliséget. A legfeljebb általános iskolai végzettségüek és a felsőfokú iskolai végzettségüek között a munkanélküliség által érintettek arányában 2,5-szeres a különbség. A legfeljebb az általános iskola 8. osztályát végzettek körében 2012-ben jelentős mértékben nőtt azok aránya, akik több alkalommal voltak munkanélküliek, illetve azoké, akik jelenleg is azok. A munkanélküliség területi különbségeit tükrözi, hogy míg a Budapesten, Pest, illetve Győr-Moson- Sopron megyékben élő 19-64 évesek több mint 72\%-a még soha nem volt munkanélküli, addig Szabolcs-Szatmár-Bereg megyében 51,5, Nógrád 
megyében 52,2, Borsod-Abaúj-Zemplén megyében csak 52,4\% ez az arány. Továbbá e megyékben jelentős azok aránya, akik már több alkalommal voltak munkanélküliek (KSH, 2012).

A negatív szelekciós hipotézis szerint az iskolai végzettség szerepét illetően megkérdőjelezhetők a pusztán csak a munkaerőpiac strukturális átalakulására építő magyarázatok. A képzettség emelkedésével a munkaadók elvárásai változnak, a korábban képzettséget nem igénylö állásokat is iskolázottabb munkavállalókkal töltik be. Másrészről a képzetlenek csoportjának összetétele is átalakul, egyre homogénebb csoportot alkotnak: egyre többen vannak köztük azok az előnytelen származású munkavállalók, akik a munkaadók által megkövetelt minimális kompetenciával sem rendelkeznek. Az iskolai végzettséggel nem rendelkezők gyakorlatilag kiszorulnak a munkaerőpiacról (Öry, 2005).

\section{Az iskolai végzettség ,értéke": a kompetenciák}

A kompetenciák szerepének növekedése napjainkban egyre eröteljesebben öszszefügg a munkaerőpiac változásaival. Szoros a kapcsolat az alapkészségek és a foglalkoztatás vagy munkanélküliség között (Köllő, 2007). Kemény István elemzéseiben a szakma, a szakképzettség legfontosabb tartalma az iskolázottság mellett az univerzalitás. Az igazi szakember az univerzális szakember, így például az esztergályos, aki rajz után el tudja készíteni a munkadarabot, méghozzá kevés fogással, gyorsan. Egy villanyszerelö, aki ha kell porszívót javít, ha kell, akkor kapcsolási rajzról bekábelez egy házat, stb. Természetesen ez az univerzalitás ez egyfajta mobilitási képességet is jelent, nemhogy lehet máshol is dolgozni a szakmában, hanem épp attól lesz valaki univerzális szakember, hogy világot látott, hogy több helyen, többféle a szakmájához tartozó munkában is megállta a helyét (Kemény, 1992).

Az alacsony végzettségü munkavállalás nem feltétlenül „,tudás-nélküliséget” jelent, hanem sokkal inkább sajátos, nem túl magasra értékelt tudások és képességek azok, amelyek az alacsony végzettségü emberek bérmunkás foglalkoztatása során értékesednek. Ez a tény összecseng Köllö János (2009) azon megállapításával, miszerint az alacsony végzettségü emberek általános kompetenciái, különösen nyelvi, szövegértési, kommunikációs kompetenciái lényegesen alacsonyabbak a fejlett országok alacsony végzettségüek mutatóinál. Köllő példáját idézve: egy teherautósoförnek a kocsi vezetéséhez sem most, sem korábban nem volt szüksége különösebben magas iskolai végzettségre. Míg azonban egy régi gazdaságban a teherautó sofőrjének a vállalat egyik telephelyéről kellett valamit átvinnie a másikra, addig ma a határokon átkelve, vámot és beutaztatást kell intéznie, fizetési-pénzügyi müveleteket kell rendeznie, stb. Ehhez alapvetően 
nem iskolára, hanem írni-olvasni tudásra van szüksége, amit ma a munkaadók leginkább abban látnak biztosítottnak, akinek az érettségije is megvan.

Az alacsony iskolai végzettség nem is feltétlenül az elsajátított ismeretek kicsiny mennyisége miatt teremt hátrányt, hanem a további ismeretek befogadására való felkészültségekben, attitüdökben, a fejlődést megalapozó kommunikációs készségekben és képességekben (Öry, 2005; Kerülö, 2009). A munkakörök betöltéséhez ma már nem elég a megfelelő végzettség, szakképzettség, gyakorlat. A fejlödés következtében gyorsan változó munkakörülmények miatt megjelent az olyan munkaerő iránti igény, aki megújulásra képes, azaz e változásokhoz gyorsan alkalmazkodik, folyamatosan átképezhető, fejleszthető. Olyan dolgozókat keresnek, akik nemcsak a szakmájukhoz kapcsolódó tudással rendelkezzenek, hanem a hatékony munkavégzéshez szükséges tulajdonságokkal is, mint a jó kommunikációs és problémamegoldó készség, meggyőző érvelés, gyors helyzetfelismerő-képesség, kompromisszumkészség, flexibilitás, mobilitás, teherbírás, stressz-türés, nyitottság és kreativitás. Mindez azt jelenti, hogy a munkaeröpiaci kirekesztődés egyik legerősebb magyarázó tényezője az alacsony iskolai végzettség és a kompetencia hiánya. Ugyanakkor az elkövetkezendő időkben a végzettség még inkább fontos lesz, elsődleges a készségekkel szemben, a kompetenciákat csak a végzettség birtokában vizsgálják a munkaadók a potenciális munkavállalók körében (Öry, 2005).

Az Európai Bizottság is megfogalmazta, hogy munkahelyteremtés a két ellentétes póluson várható: a magasabb szintü és az alacsonyabb szintủ tudást igénylő munkakörökben. Ugyanakkor az alacsonyabb végzettséget, készségeket igénylö munkahelyeken is egyre inkább elvárás a nem rutin feladatok ellátása. Éppen ezért szükséges hangsúlyt fektetni a készségek fejlesztésére, és arra, hogy a készségek illeszkedjenek a munkaerőpiachoz. Érdemes az élethosszig tartó tanulásra fordított kiadásokat növelni, figyelembe véve azt a szempontot, hogy a humán erőforrásba való befektetés gazdaságilag megtérül. A gyors változások miatt az újonnan kialakuló munkahelyekhez új típusú készségek szükségesek, így nemcsak a munkanélküliek, hanem a már dolgozók alkalmassá tétele, foglalkoztathatóságuk fejlesztése is fontos szempont kell, hogy legyen. A kompetenciák fejlesztésének feltétele a magas minőségü alapoktatás, a lemorzsolódás megelőzése, valamint az oktatásban, képzésben való részvétel fejlesztése. A felnőttképzések lehetőséget adnak a résztvevők kompetenciáinak fejlesztésére, melyek növelhetik az egyének kereseteinek nagyságát. A különböző készségek, képességek megléte további mérhető munkaerö-piaci előnyökkel járhat, hatással lehet a foglalkoztatási esélyek javulására (Varga, 2006). Ezért Magyarországon elsősorban az érettségit nem szerzett felnőttek esetében lenne a legnagyobb szükség az alapkészségeket pótló képzésekre (Köllö, 2007). 


\section{A hátrányos helyzetü felnőttek tanulását nehezítő tényezők}

Ezen tényezők jó része a tanulón kívülről származhat, például tanulását nem támogatja közvetlen családi vagy munkahelyi környezete. A nem megfelelö oktatási környezet is számos nehézség forrása lehet: az intézmény légköre nem támogató, nem segíti a hiányzó előzetes ismeretek pótlását, a felzárkóztatást, nem elég rugalmasak, az oktatásszervezés formái, a felnőtt nem tud alkalmazkodni, nincs választási lehetősége. Külső nehezítő tényező lehet a nem megfelelő tanári, oktatói munka, az andragógiai ismeretek és kompetenciák hiányos volta, a tanárok elutasító attitüdje, stb. Érdemes megjegyezni, hogy e tényezők hatása erősen függ attól, hogy a tanulóknak milyen fejlett a nehézségekkel történő megküzdési képessége (Bajusz, 2005). A hátrányos helyzetű felnőttek tanulását nehezítő tényezők másik csoportja inkább magából a tanuló felnőttből ered. Gyakori, hogy korábban rögzült szokások és hiedelmek akadályozzák a tanulást, különösen a tanuló önképét negatívan befolyásoló felfogások, mint például a gyakran elhangzó ,én ezt már nem tudom megtanulni” meggyőződés. Az életkor előrehaladtával a képességek, a testi erő fogyatkozásával csökken a felnőttek tanulói önbizalma. Alábecsülik képességeiket, túlságosan sokat aggódnak teljesítményük miatt. Erős gátja a felnőttkori tanulásnak a megszégyenüléstől való félelem, valamint a korábbi rossz iskolai élmények hatása. (Kerülő, 2009). A negatív érzések mellett a stressz, illetve a stresszkezelési technikák hiánya a felnőtt tanuló nagy problémája. A felnőtt, ha hosszú ideig stressz állapotban van, csökken a kommunikációs képessége, rosszabb tanulási teljesítményt mutat (Farkas, 2013).

A korábbi tanulási technikák fejletlenségével függ össze a meglévő tudás és az új ismeretek összekapcsolásának nehézsége. Nem mindig, vagy csak segítséggel sikerül felidézni a korábban már tanultakat. A nehézséget növeli, ha a felnőtt emlékezetében a meglévő tudás elkülönült elem, nehéz előhívni, összefüggések nélkül összekapcsolni, különösen akkor, ha a tanulási tapasztalatok és technikák nem eléggé fejlettek. Ennek egyik oka lehet, hogy fiatalabb életkorban a tanulás célja nem a teljesítőképes tudás megszerzése volt, hanem az ismeretelsajátítás. A tanulási motiváció csökkenését eredményezheti, ha a felnőtt tanuló számára a tanulás értéke nem ,itt és most” jelentkezik, ezért nem is vállalkoznak szívesen hosszú időtartamot felölelő tanulási programokra. (Kerülő, 2009; Farkas, 2013; Bajusz 2009). 


\section{Alacsony képzettségüek és közfoglalkoztatottak képzése}

A tartós munkanélküliség jelenléte, a munkanélküliek számának és körének szélesedése napjaink egyik legégetőbb gazdasági és társadalmi problémája. A piaci alapokra építő oktatási rendszer következtében a rosszabb anyagi körülmények között élő, nehezebben tanuló, eleve hátrányos helyzetű társadalmi rétegek tanulási esélyei nagy léptékben csökkennek. Ez a hátrány egyrészt folyamatosan halmozódik, hiszen az alacsony iskolázottság következtében a munkaerőpiacon is előnytelen pozícióba kerül az egyén, másrészt könyörtelenül újratermelődik a jelenség. Az Európai Unió Lifelong Learning Munkaprogramjának egyik legfontosabb célkitüzése az Európai Unión belüli oktatási és képzési rendszerek minőségének és hatékonyságának növelése, különös tekintettel a 24 és 64 év közötti populáció körében (Eurostat, 2012). A felnőttképzés eredményességének azonban több tételtől függ.

Alapvető fontosságú a kitüzött célok eléréséhez a tanterv gondos megtervezése, hozzá a megfelelő minőségü tananyag elkészítése, természetesen a felnőttképzés módszertani alapelveinek figyelembevételével. Az eredményes munka érdekében meghatározó szerepe van a tanári munka minőségének is, így a képzési folyamat eredményességének legjelentősebb fokméröje a felnőttoktató szakmai, módszertani, emberi felkészültsége, rátermettsége. Nem kétség, hogy a tanulás hatékonysága nagymértékben növelhető, ha az oktató jól ismeri a felnőtt tanuló sajátosságait, elvárásait és az eredményes tanulást biztosító ismeretszerzési folyamat mozzanatait. Több szakember is egyetért abban, hogy a képzési piac elvárásainak változásai, és a megrendelők igényeinek növekedése egyre sajátosabbá teszi azt az elvárást, miszerint a felnőttoktató a szakismeretek mellett biztos felnőttképzési, módszertani ismeretekkel és jártassággal is rendelkezzen, amely elengedhetetlen ahhoz, hogy az oktatott ismeretanyagot a felnőttkorban tanulók összetételének megfelelö, legjobb módszerválasztással és a legeredményesebben tudja oktatni (Farkas, 2013; Bajusz-Németh, 2011). A tanár-diák viszonyban az alá-fölérendeltség helyett a partneri viszony a kívánatos és célravezető felfogásmód. A szakmai felkészültség mellett az empátia, a rugalmasság, az elöítélet mentesség, a hitelesség a felnőttoktató kívánatos személyiség jegyei.

A fent említett szempontoknak és elvárásoknak a figyelembevétele a hátrányos helyzetű felnőttek esetében fokozottabban érvényesek. A hátrányos helyzetủ és speciális csoportokkal foglalkozó andragógusoknak speciális kompetenciákkal is kell rendelkezniük. A célcsoportok iskolai végzettsége alapján külön kiemelendő az alacsony iskolázottságúak célcsoportja, akár tartós munkanélküliek, akár gyesen, gyeden lévők, netán 45 év felettiek. Az ilyen célcsoportok ese- 
tében a képzés fó célja többnyire a hiányzó alapkészségek és az alapmüveltség pótlása, a munkaerő piacon keresett és használható kompetencia elsajátítása. Amennyiben a képzés fô célja a hiányzó alapkészségek pótlása, úgy bizonyos tanítóktól elvárt módszertani felkészültséggel kellene rendelkeznie a felnőttoktatónak (Bajusz, 2009).

A GINOP-6.1.1-15 kódszámú „Alacsony képzettségüek és közfoglalkoztatottak képzése" című kiemelt projekt célja, hogy ösztönözze az alacsony iskolai végzettséggel, munkaerőpiacon keresett kompetenciával vagy szakképesítéssel nem rendelkező felnőtt lakosság részvételét az oktatásban, képzésben, és lehetőséget biztosítson számukra a munkaerö-piaci szempontból releváns képzettség, ismeretek, készségek, kompetenciák megszerzésére. Jelen tanulmányban egy ilyen képzésben szerzett tapasztalatainkat vettük számba, andragógus szemmel vizsgálva a képzésben résztvevők örömeit, sikereit, nehézségeit. Mindezt megfigyeléses módszerrel valamint fókuszcsoportos interjúk segítségével tettük.

Az alapvégzettséget meg nem szerzett vagy alulképzett felnőttek esetében jellemző motivációhiány oka legtöbb esetben a korábbi rossz iskolai tapasztalatokban, a tanulási kudarcélményekben keresendő, valamint abban, hogy családjuk, környezetük, s így önmaguk számára sem érték a tudás, illetve a tudásszerzés folyamata (Farkas, 2010; Kerülő, 2009; Bajusz-Németh, 2011). Környezetükben nem jelenik meg mintaként az az életforma, mely természetes folyamatként kezeli akár az iskolai, akár az iskolarendszeren kívüli tanulás felnőttkori megjelenését. Mivel munkaerő-piaci helyzetük is labilis, a külső motivációs tényezők hatására sem ülnek vissza az iskolapadba. Így nem alakul ki az a motiváció, melynek hatására létrejöhetne a tanuláshoz szükséges anyagi fedezetet, a családban a tanuló felnőtt segítését szolgáló munkamegosztást és nyugodt érzelmi hátteret megteremtő attitüd (Farkas, 2010; Kerülö, 2009).

A GINOP-6.1.1-15 kódszámú „Alacsony képzettségüek és közfoglalkoztatottak képzésé"'-nek a lényege, hogy a már meglévő hat elemi osztály befejezése után a 7-8. osztályt is sikeresen elvégezzék a hallgatók, ezzel lezáruljanak - a korábban valamilyen oknál fogva félbemaradt - általános iskolai tanulmányaik. A nem a megszokott keretek között zajló oktatás rendkívüli előnye, hogy mindössze fél éves időintervallum alatt elvégezhetik a hallgatók a nappali képzésen egyébként két évig tartó 7. és 8. osztályt. A hallgatók szempontjából igen fontos tény továbbá, hogy a tanfolyam ideje alatt úgynevezett megélhetést biztosító juttatást is kaptak havonta a képzésben résztvevők. Emellett lehetőség volt helyközi autóbusz bérletek térítésére is. Sokaknál ezek a juttatások jelentették a legföbb motivációs erőt, ami sejteti nehéz anyagi helyzetüket, szociális gondjaikat.

A képzési program 11 modulból (tantárgyból) álló tananyagcsomagot tartalmazott: magyar nyelv és irodalom; matematika; fizika; kémia; informatika; környezetvédelem - földünk és környezetünk; biológia; pályaorientáció; történelem és állampolgári ismeretek, müvészeti ismeretek; idegen nyelv (angol). A tananyag- 
csoportok az alábbi kompetenciák megszerzésére irányulnak: Matematikai ismeretek (a mindennapi élethez kapcsolódó számítási műveletek önálló elvégzése, ezáltal a szakmai számítások megalapozása), Magyar nyelv és irodalom (magabiztos írás-olvasás, a különböző müfajú olvasott anyag lényegének, illetve önálló gondolatoknak a megfogalmazása szóban és írásban), Informatika (tudja kezelni az alapvető informatikai eszközöket, ismeri a szövegszerkesztés és táblázatkezelés alapjait, tud az interneten keresni és levelezni), Történelem és társadalomismeret (ismeri a legfontosabb társadalmi-történelmi változásokat, azok jelentőségét, ismeri a politikai jogok gyakorlásához szükséges intézmények szerepét), Természetismeret (ismeri a kémia, fizika, biológia és a földrajz témaköreit, ezeket felismeri a hétköznapi tapasztalatokban, illetve környezetében), Idegen nyelv (megért és válaszol tagoltan feltett, egyszerü, önmagát és közvetlen környezetét érintő kérdésekre, tud köszönni, bemutatkozni, és elemi szükségleteit ki tudja fejezni, el tud olvasni egyszerủ tájékoztató feliratokat, ki tud tölteni egy személyes adatait, kérő ürlapot), Pályaorientáció (ismeri saját képességeit, lehetőségeit a munka világában, rendelkezik a munkavállaláshoz szükséges pozitív jövőképpel).

\section{A nyíregyházi képzés tapasztalatai}

A nyíregyházi csoport 2015 májusában 15 fôvel indult - 4 féri és 11 nő -, végül 6 fő fejezte be sikeresen. Korösszetétel alapján igen változó a kép, a legfiatalabb hallgatók 18-20 év közöttiek, a legidősebb pedig a 60. életévét is betöltötte.

A 4 férfi a „B” kategóriás jogosítvány és építőgép kezelői jogosítvány nyolc általános iskolához való megkötése miatt jelentkezett a képzésre. Az egyik női résztvevő fö motivációs ereje is a jogosítvány megszerzése volt - a sikeres záróvizsgát követően elmesélte, hogy bár még mindig ez az álma, de egyelőre anyagi gátjai vannak a megvalósításnak.

A szakmában való elhelyezkedés illetve a továbbtanulás csak néhányukat motiválta, ami korcsoportonként is megoszlást mutat. Középfokú végzettségre inkább a fiatalabb korosztály szeretne szert tenni a későbbiekben (9 fö), az idősebbek (6 fö) inkább valamilyen biztos megélhetést, anyagi hátteret jelentő szakmát tanulnának, mint például szakács, fodrász.

A tanfolyami oktatást egy általános szürés előzte meg, melynek célja volt, hogy a képzésre legalkalmasabb - legmotiváltabbak, leginkább rászorultak, mentálisan legrátermettebbek -kerüljenek be a tanfolyamra. A teszt két részböl állt: egy nyelvi és egy matematika szintfelmérőből. A nyelvi teszt több feladatból állt, így árnyaltabb képet adott a kitöltőjéről, alaposabban mutatta meg meglévő ismereteit illetve bizonytalanságait. A kis- és nagybetük megkülönböztetése, ékezetek megléte vagy hiánya, tulajdonnevek helyesírása okozta a legtöbb 
problémát. Az eredmények a vártnak megfelelően rendkívül vegyes képet mutattak. Született néhány száz százalékos dolgozat, de 40 százalék alatti eredmények, sőt nulla pontos feladatsorok is előfordultak.

Az oktatás minden munkanapon délelött - hétfőtől péntekig - napi 6 órában, azaz 3X2 vagy 2 X3 modulban zajlott. Az órarend összeállításánál fontos feladat volt, hogy az egyes modulok ne legyenek túlságosan tömbösítve, tehát ne legyen egyik modulból sem túlságosan sok egy nap vagy egymást követő napokon. Ennek figyelembe vétele lényeges volt a tananyag könnyebb elsajátítása szempontjából. A tanuláson és az ismeretszerzésen túl a hangsúly a résztvevők képességfejlesztésén volt, melyet differenciált oktatás formájában igyekeztek a tanárok megvalósítani. Bár csoportbontás nem történt a kis létszám miatt, a gyorsabban haladó tanulók plusz feladatokkal illetve több önálló, egyéni munkával bővítették ismereteiket. A kitüzött célok eléréséhez szóbeli és írásbeli dolgozatok illetve modulzáró vizsgák teljesítésén keresztül vezetett az út.

Az igen vegyes csoportösszetétel miatt - minden tantárgy esetében - elöször ismétléssel egybekötött szintfelmérést végeztek az oktatók, majd az egyéni készségeket, képességeket is figyelembe véve igyekeztek személyre szabott oktatást megvalósítani. Bár az alacsony óraszámok miatt feszített volt a munkatempó, nagyon fontos volt, hogy minden tanulónak próbáljanak időt hagyni a felzárkózásra, a tananyag megértésére, elsajátítására. A fiatalabb korosztály számára kezdeti elönyt jelentett, hogy ök nemrég fejezték be tanulmányaikat, így emlékezetükben még frissebben élt a tananyag és a tanulói légkör sem volt idegen számukra. Az idősebbeknek nemcsak a hiányos ismeretek okoztak gondokat, de maga a tanulás tevékenysége is megerőltető volt. Mindezek ellenére sokkal érdeklődőbbek, elszántabbak, motiváltabbak voltak, sokan odahaza saját gyerekeikkel együtt tanultak, ismételtek még az iskolai tanórák után is. ,Alapvetően örültek, bár eleinte a gyerekeim megmosolyogtak, amikor bejelentettem, hogy iskolába fogok járni. De aztán látták rajtam, hogy mennyire komolyan veszem a tanulást és ez nekik is példa volt, amit remélem, jól meg is jegyeztek." (József 27 éves).

A program indulásakor mindannyian tartottak attól, hogy nem fognak megbirkózni az iskolai követelményekkel. Ebben segített az első másfél hét alatt lezajlott ráhangoló és motiváló tréning, amely nehezen indult, sokaknak céltalannak tünt. Ezek az emberek rengeteg gátlással és félelemmel érkeztek az órákra, így ezeket a feszültségeket oldani kellett a komolyabb tanulás megkezdése elött. A tréning alatt többen megjegyezték, hogy már elöre féltek a tananyag mennyiségétől, mondván, hogy ez nekik eddig sem ment - náluk különösen fontos volt a megerősítés és a sikerélmény. „Én másodikos voltam, amikor kivett anyukám az iskolából, tovább nem engedtek a szüleim iskolába járni. Mindig is nagy vágyam volt, hogy megtanuljak olvasni és le tudjam írni jól a nevemet." válaszolta Éva (38 éves). 
A tréning nemcsak a kezdeti feszültséget oldotta, de a viselkedéskultúrájukat is fejlesztette, melyet a tanórák alatt tovább mélyültek: „Nehéz volt azt megszokni, hogy az iskolapadban máshogy viselkedik az ember, hogy például nincsen hangoskodás, bekiabálás. Ez végül nem volt olyan nehéz, mint az elején gondoltuk. Sokat beszélgetünk és helyzetfeladatokat is csinálunk, és a számolásban is ügyesebbek leszünk. Rájöttünk, hogy jó, ha figyelmesen meghallgatjuk a másikat, hogy együtt tanulunk, és kölcsönösen elfogadjuk és tiszteletben tartjuk egymást." (Vera 33 éves).

A csoport egyharmada valamilyen tanulási nehézséggel küzdött. Beszédhibát és tanulási zavart is diagnosztizáltak náluk általános iskolai tanulmányaik során. Néhányuknál diszlexiás, diszgráfiás tünetek is jelentkeztek, egy két kivételtől eltekintve, a folyamatos olvasás, írás is nehézséget okozott. Írásuk olvashatatlan volt a kezdetekkor, de a tanfolyam végére írásképük olvashatóbbá vált és könnyebben olvastak. „Nagy dolog az, hogy kap az ember egy számlakivonatot és el tudja olvasni, mi áll benne. Jó érzés, hogy helyesen tudjuk leirni, hogy hol lakunk. Olyan boldogságot ad az, hogy alá tudjuk írni a nevünket! A csoportból nem csak engem érintett ez a probléma, hanem többeket is, de itt mindenki nagyon sokat tesz a fejlödéséért és sokan vagyunk, akik öszintén akarunk!'”(Ilona 29 éves).

Volt egy anya (nagymama) és lánya páros, akik az unokával együtt tanultak otthon, sőt a nyári szünetben a gyereket is hozták magukkal az órákra. „Én nem nevettem ki öket, hogy olyan feladatokat kapnak anyáék, amiket én is tanulok az iskolában... büszke vagyok rájuk, ahogyan ök is örültek a jó bizonyítványomnak." (Kitti 8 éves).

De nemcsak ismeretek, készségek, kompetenciák megszerzése eredményezett sikerélményt a résztvevőknek. Nemcsak az a cél, hogy piacképes készségeket nyújtsunk a munkanélküli fiataloknak, és idősebbeknek, hanem az, hogy pozitív hozzáállást alakítsunk ki bennük a tanulás és egy magasabb életminőség iránt. A tanulást ne intézménnyel, tanárral, ne félelmekkel terhelt helyzettel kapcsolja össze a felnőtt, hanem szabadsággal, örömforrással, pozitív életérzéssel. Erre példa Marika, a képzés legidősebb résztvevőjének interjú válasza: ,, Van 11 unokám, 4 dédunokám, segítek nekik ezzel a kis pénzzel is, amit a tanulás mellé megélhetési támogatást kaptunk.” - mondja Marika (60). „Megbecsülnek a gyerekeim, én is itt a fiatalokat, szót értek mindenkivel. Tudom, hogy szegény vagyok s nem okos, de jó embernek tartom magam. ..Voltam az öngyilkosságig elkeseredett, de az iskola nekem segitett: nem vagyok depressziós, reggel vidáman kelek, alig várom, hogy a padban legyek. Tudom minden nap: hova megyek, nyugalomba, ahol elfogadnak, nem bánt senki, s sokat tanulok. Akarok újabb ismereteket szerezni, ha lehet, még ezután is! Nem akarok arra gondolni, mi lesz, ha vége a tanfolyamnak."

Ezek az interjúrészletek tanúsítják, hogy az aluliskolázott rétegek számára a tanulási képességeket, a szociális alapkészségeket fejlesztő, önbizalom növelő 
tréningek sokat segítettek a kezdeti félelmek leküzdésében, ezért a tréneri kiképzés is fontos része lehet a csoportot fejlesztő felnőttoktatók felkészültségének. A tanácsadás-orientálás mellett a segítő-támogató szerep is nagy jelentőséggel bír a tanulási folyamatok megindulásában és fenntartásában. A tutor és mentor szerepek felkarolása és továbbfejlesztése feltétlenül szükséges ahhoz, hogy a hátrányos helyzetű rétegek eséllyel vegyenek részt tanulási folyamatokban (Farkas, 2013). Kiemelt fontosságú volt a minél változatosabb szemléltetés - a rendszeres órai vázlat, táblarajz, projektoros diavetítés, dokumentumfilm vetítés, atlaszok illetve falitérképek használata - hiszen ezeknél a felnőtteknél különösen fontos, hogy egyszerre több érzékszervükre is ható, élményszerü legyen a tananyag. Ennek érdekében sok-sok gyakorlással és gyakoroltatással, egyénileg és közösen megoldott munkafüzeti feladatokkal teltek az órák. Akkor tanultak lelkesebben, ha bevonták őket a tanulási feladatokba, ha a feladataik összhangban voltak önképükkel, felnőttes felelősségtudatukkal. Egyik interjúalanyom kérdésemre, melyben arról érdeklődtem, hogy mivel volt elégedett a képzés során, elsőként az oktatóval kapcsolatos elégedettségéről beszélt: ,, a tanárok nagyon jók voltak, magyaráztak is, és kérdeztek minket is. Azt oktatták, amire kiváncsiak voltunk, meg amivel ök is foglalkoztak...” „Nem az a katonás rend volt, nem úgy oktattak, mint régen az iskolában. Szabadabb volt a légkör..." Ebböl is látszik, hogy mennyire jelentős a naprakész, gyakorlatias és hiteles oktató, aki a felnőttek igényeinek megfelelően, a felnőttképzés didaktikai módszereit alkalmazva irányítja, segíti a képzésben résztvevőt.

Az ellenőrzés és értékelés napi szintü volt, ami az óra végi összefoglalások alkalmával, dolgozatok megbeszélése után mind szóbeli, mind pedig írásos érdemjegy - formában kaptak. Egyénileg és csoportosan is alkalmazták az oktatók, hiszen a felnőtt tanulók ennek alapján kaptak visszajelzést pillanatnyi tudásukról, tanulmányaik előrehaladásáról, esetleges hiányosságaikról és ezek korrigálásának módjáról. Visszatartó tényezőként hat a felnőttre, ha nem látja világosan a képzés által nyújtott tudás, képesség reális, értelmes célját, megtérülését, ha a megtanultakkal kapcsolatban nem kap kellő időben és módon visszacsatolást, ha nem kezelik felnőttként - kiváltképp, ha ehhez párosul egy korábbi rossz tanulási tapasztalat -, ha nem veszik figyelembe felmerülő problémáit, életkörülményeit, vagy ha rossz, esetleg fenyegető érzettel tölti el a csoportlégkör (Zrinszky, 2008).

Azt tapasztaltuk, hogy lényeges a felnőttoktató szociálpszichológiai felkészültsége is, hiszen a csoportokban való tanulás olyan hatásokat is kifejt a csoporttagok magatartásának, viselkedésének, tudásának a változására, amit részben tervezni, részben kontrollálni érdemes.

Ajánlatos erősíteni a nem formális tanulás során szerzett kompetenciák elismerésére szolgáló mechanizmusok rendszerét is, hiszen a nem formális környezetben - akár önkéntes munka során is - folyamatosan fejlődhetnek a képessé- 
gek. Nemcsak a beszámítás céljából fontos a nem formális környezetben szerzett tanulási eredmények felmérése, hanem azért is, mert ezáltal „szembesíteni” tudjuk a felnőttet, hogy sokkal többet tud és sokkal többre képes, mint azt saját magáról gondolta volna (Farkas, 2013). Hangsúlyozni kell, hogy a tanulás örömforrás, tartalmasabbá és könnyebbé teheti az emberi életet. Olyan erkölcsi hozadékkal jár, amely a közösségen belül kiemelt pozíciókat biztosíthat. A tanulás a szabadság eszköze is, mivel nagyobb fokú szabadságot ad az, ha az ember mer önállóan dönteni, saját sorsát a kezébe venni. A valahová tartozás tudatának kialakítása szintén olyan előny, amelyről nem szabad megfeledkezni. Jelenleg az ilyen fajta erkölcsi hozadékot az emberek nem mérik fel, így elfelejtik a várható pozitív eredmények közé sorolni.

\section{Befejezés}

Egy ilyen típusú, összetett felzárkóztató képzésnek elvileg több hasznosulása is bekövetkezhet: a résztvevőknek nemcsak új ismereteket kell elsajátítani, de másféle gondolkodásmódot, és másféle emberi kapcsolatokat is ki kell alakítani, mint amit eddig megszokott. Az Európai Unió Lifelong Learning Munkaprogramjának „lifelong learning gondolkodása” magában foglalja a készségek, ismeretek, végzettségek megszerzését és továbbfejlesztését, a tanulási képesség és az alkalmazkodó képesség fejlesztését, a problémahelyzetek megoldását. Ezenkívül fontos szerepet kap a felelős, cselekvő állampolgári magatartást fejlesztése és gyakorlása is, amelyre a hátrányos helyzetben élő felnőttek még fokozottabban szükségeltetnek. Ebben az esetben nem a hagyományos formális tanuláson van a hangsúly, sokkal inkább a kultúra és az emberi élet újszerü kapcsolatáról, a mindennapokban való eligazodáshoz szükséges ismeretrendszerről, a felnőttkori szocializáció folytonosságának alapjáról. Meg kell értetni ezzel a társadalmi réteggel, hogy a tudás esélyt teremt, enyhítheti a szegénységet, a kiszolgáltatottságot, ,ablakot nyit a világra" (Durkó, 1999). Összegzésként elmondható, hogy a felnőttek sok erőforrással rendelkeznek a tanuláshoz. Számos belső és külső hatás által segítve illetve korlátozva, de képesek és készek is tanulni. Számos tudomány járul hozzá a felnőttek fejlődésének és tanulásának jobb megértéséhez, s ezzel biztos alapot építve a gyakorlat számára. Mivel a felnőttoktatás multidiszciplináris alapon nyugszik, a felnőtteket oktató szakemberek, andragógusok, oktatás-, és képzésszervezőknek kell megtenniük, hogy sok irányban tájékozódjanak, hogy ismereteiket összevessék saját tapasztalataikkal, és személyes megközelítést, saját elképzeléseken alapuló munkamódszert alakítsanak ki hallgatóikkal, a tanuló felnőttekkel. 


\section{Felhasznált irodalom}

1. Bajusz Klára - Németh Balázs (2011): Felnőttoktatási felfogások a 20. században. In: Andragógia Szöveggyüjtemény I. Pécs, Publikon Kiadó.

2. Bajusz Klára (2009): A felnőttkori tanulás motivációi. Felnőttkori tanulási képességek http://ofi.hu/tudastar/esely-2000-konferencia/felnottkori-tanulas (2015.10.10.)

3. Durkó Mátyás (1999): Andragógia - A felnőttnevelés és a közművelődés új útjai. Magyar Müvészeti Intézet, Budapest, 115-116. p.

4. EUROSTAT (2012): Population aged 25 to 64 participation in education and training. http://epp.eurostat.ec. europa.eu/statistics_ explained/ index.php?title=File:Lifelong_learning, 2006_and_2011_(1)_(\%25_of_the_p opulation_aged 25 to 64_participa (2015. 10. 10.)

5. Farkas Éva (2012): A szak- és felnőttképzés gyakorlata. SZTE JGYPK Szeged.

6. Farkas Éva (2013): Láthatatlan szakma. Tények és tendenciák a felnőttképzés 25 évéröl. typiART 2013.

7. Fazekas Károly - Köllő János - Varga Júlia (szerk.): 2008. Zöld könyv a magyar közoktatás megújításáért, Budapest, Ecostat.

8. Ferge Zsuzsa (2010): Társadalmi áramlatok és egyéni szerepek, Budapest, Napvilág Kiadó.

9. GINOP-6.1.1-Alacsony képzettségüek és közfoglalkoztatottak képzése. http://ginop611.hu/ginop-6-1-1-3 (2015. 10. 10.)

10. Kemény István (1992): Szociológiai írások, Budapest, Replika Könyvek.

11. Kerülő Judit (2009): Hátrányos helyzetü csoportok és a felnőttoktatás. www.oki.hu/oldal.php?tipus (2015. 10. 10.)

12. Kertesi Gábor- Kézdi Gábor (2009a): Általános iskolai szegregáció Magyarországon az ezredforduló után. Budapesti Munkatudományi Füzetek, 5. sz. Budapest.

13. Kertesi Gábor- Kézdi Gábor (2009b): Szegregáció az általános iskolákban. Számítások a 2006. évi országos kompetenciamérés adatain. In Fazekas, Károly-Telegdy Álmos (szerk.): Munkaerőpiaci tükör. Budapest, OFAMTA KTI.

14. Koltai Dénes (1999): A felnőttoktatás feladatai, Educatio, 1999/1, 14-21.

15. Köllő János (2009): A pálya szélén - Iskolázatlan munkanélküliek a posztszocialista gazdaságban, Budapest, Osiris.

16. Köllő János (2007): Foglalkoztatáspolitikai eszközök az érettségivel nem rendelkezők munkaerő-piaci helyzetének javítására és az oktatási reformok előmozdítására. 
http://oktatas.mholnap.digitalnatives.hu/wiki/foglalkoztat $\% \mathrm{c} 3 \%$ a1 spolitikai eszk\%b6z\%c3\%b6k (2016.10.12.)

17. Központi Statisztikai Hivatal: 2012. Munkanélküliség által érintettek, 2012, Statisztikai Tükör, VI. évfolyam 106. szám.

18. Öry Mária (2005): Hátrányos helyzetű csoportok helyzete a munkaerőpiacon, Budapest, Nemzeti Felnőttképzési Intézet.

19. Sen, Amartya: (2009): The Idea of Justice, Cambridge Massachusets, Belknap Press of Harward Univ. Press, idézi Ferge Zsuzsa: (2010): Társadalmi áramlatok és egyéni szerepek, Budapest, Napvilág Kiadó.

20. Varga Júlia (2006): Humántőke-fejlesztés, továbbtanulás felnőttkorban, "skill”-ek és kompetenciák. In Kolosi Tamás- Tóth István GyörgyVukovich György (szerk.): Társadalmi Riport, Budapest, Tárki, 287-300.

21. Zrinszky László (2008): A felnőttképzés tudománya. Budapest. Okker Kiadó és Kereskedelmi Kft., 25-30.

\section{Nyilas Orsolya}

Andragógus, közmüvelődési szakember. A Nyíregyházi Egyetem Társadalom és Kultúratudományi Intézetében tanársegéd. 1998-ban végzett a Bessenyei György Tanárképző Főiskola magyar-művelődésszervező szakán, majd 2004ben a Debreceni Egyetemen Müvelődési- és felnőttképzési menedzser lett. 2004 óta tanít a felsőoktatásban. Szakmai érdeklődése a felnőttképzés módszertana, oktatásszervezés, rendezvényszervezés, andragógia területeire irányul. Jelenleg a Debreceni Egyetem Nevelés- és Müvelődéstudományi Doktori programjának doktorandusza. Kutatási területe az alacsony végzettségüek és hátrányos helyzetű felnőttek tanulási motivációja, lemorzsolódásuk okai, kvalifikáltságuk növelésének lehetőségei. 